\title{
THE RELATIONSHIP BETWEEN CONCENTRATION OF THE BANKING SECTOR IN POLAND AND ITS SOUNDNESS
}

\author{
Karolina WóJCICKA ${ }^{1}$
}

Abstract

\begin{abstract}
Each year assets of the banking sector in Poland increase and thereby its significance in the real economy increases as well. At the same time, the ongoing consolidation process and changes in the ownership structure cause the Polish banking sector to play a substantial role not only on the local financial market, but on the European market as well and Polish banks are becoming more and more significant entities in their international banking groups (both in Europe and worldwide). However, the perspective of concentration increase and restriction of the Polish banking sector to a few operating banks (dominated by entities with foreign capital) is a source of distress in the context of its soundness - and due to its significance in the Polish economy - to the whole financial sector and real economy.

The main goal of this article is to analyse the changes of concentration in the banking sector in Poland, including the ownership concentration, while attempting to determine its soundness (using the financial stability ratios method). The purpose of the study is also to prove a thesis that limited concentration with diversification of the ownership structure and its limited concentration favours thesoundness of a banking system. The study was carried out on the basis of an analysis of literature (both Polish and English) and comparative analysis (of the concentration of the Polish banking sector against other European countries). Qualitative analysis was complemented with quantitative research, based on analysis of statistical data.
\end{abstract}

JEL classification: F65, G15, G21, G32

Keywords: banking sector concentration, Polish banking sector, financial soundness, financial stability,ownership structure, foreign capital 


\section{INTRODUCTION}

The economic imbalances which were revealed by the 2007+ financial crisis have intensified the economic and academic debate on the issue of the optimal size and concentration model of banking sectors, especially pointing out significant systemic risk, risk of institutions too big to fail, and risk generated by cross-border banking. At the same time, an ongoing consolidation process across all countries was observed - also in Poland. The consolidation in the Polish banking market has various causes, including: consequences of the last financial crisis, global mergers and acquisitions ( $M \& A)$, restructuring of international banking groups, or need of non-organic growth in order to gain effectiveness of scale and increase market share.

In Poland, as in most CEE countries, the banking sector plays the major role in the financial system. Therefore, it is of great importance to analyse all possible threats to its soundness - increased concentration potentially being one of them.The main goal of this article is to analyse the changes of concentration in the banking sector in Poland, including the ownership concentration, while attempting to determine its soundness (using the financial stability ratios method). The purpose of the study is also to prove a thesis that limited concentration with diversification of the ownership structure and its limited concentration favours stability of a banking system. The study was carried out on the basis of an analysis of literature (both Polish and English) and comparative analysis (of the concentration of the Polish banking sector against other European countries). Qualitative analysis was complemented with quantitative research, based on analysis of statistical data.

\section{CONCENTRATION-STABILITY VS. CONCENTRATION-FRAGILITY - AN ONGOING DISCUSSION}

The issue of market size and concentration has been of interest to many scientists, regulators and banking professionals. Especially the 2007+ financial crisis revealed macroeconomic imbalances and therefore, it made many people further ponder the question of proper size of single entities within the financial sector and the optimal level of its concentration.

Kindleberger (1978) and Minsky (1982) argued that financial instability and crises are facts of economic life and are inevitable. Minsky defined financial instability as a process in which rapid and accelerating changes in the asset prices take place relative to the prices of current output. After each boom, overtrading and financial distress will come. This means, that no matter what the structure of the sector is (both asset concentration and ownership concentration), sooner or later the soundness of the sector will be endangered. However, there are questions about what kind of breakdown the sector will be faced with (a cyclical crisis in the whole sector or a series of smaller crises) and what the consequences may be - and here the outcome, according to scientific theory, may be dependent on the sector's structure.

Economic thought and empirical evidence provide conflicting predictions about the correlation between banking concentration and financial stability (Heimeshoff\&Uhde, 2008), and therefore over the years two main thoughts have been developed in the theoretical literature: concentration-stability and concentrationfragility. The aim of this chapter is to examine what available research says regarding the possible influence of a lower or higher concentration of the banking sector on its soundness.

The concentration-stability view indicates that consolidation, and in turn an increase of concentration, provides various benefits for the banking sector. Highly concentrated and less competitive banking sectors are often associated with a lower probability of banking failures. In a less concentrated sector there is a higher number of active banks, and this in turn leads to a strong competition. Craig and Dinger (2010) state that such conditions lower banks' profitability and undermine their stability, as banks with less market power are more likely to choose risky strategies. On the other hand, in more concentrated sectors these effects are reversed and as a result lead to a lower level of non-performing loans (Kozak, 2013, p. 14). Large scale of activity enables banks to achieve economies of scale, which in turn may lead to reduction of operating costs and improvement of both profitability and solvency levels- monopolistic banks may use higher profits to build up a capital buffer (by retaining profits), which will protect them in the case of external macroeconomic shocks. This has been also confirmed by Berger, Klapper and Turk-Ariss (2008), who claim that banks with a higher degree of market power have less overall risk exposure.

The article is an effect of the project - „Financialization- impact on the economy and society"- international conference, conducted by the University

of Information Technology and Management in Rzeszów with Narodowy Bank Polski under the scope of economic education programme 
What is more, larger banks tend to be more diversified (in terms of: banking model, offered products and geographical reach) - as opposed to small banks which often run on a specialized bank model - and therefore reduce concentration risk. It is also believed that a smaller number of big banks may be easier for regulatory authorities to effectively supervise and analyse, which in turn may lead to a decline of system-wide contagion (Davis, 2007).

Tabak, Guerra, Lima and Chang (2007) tested the relation between non-performing loans (NPL) in the Brazilian banking system and macroeconomic factors, systemic risk and banking concentration. The result indicated that banking concentration has a statistically significant impact on NPL, suggesting that more concentrated banking systems may improve financial soundness through reduction of bad loans. Beck, Demirgüç-Kunt and Levine (2003) also investigated the impact of bank concentration and regulations, bank ownership and the overall competitive and institutional environment on banking system fragility using crosscountry data on 70 countries and 47 crisis episodes. The authors have proven that bank concentration has a stabilizing effect and that concentrated banking systems are less likely to experience systemic banking crises. In the course of their research they confirmed that the overall impact of concentration on fragility is negative.

On the other hand, the concentration-fragility hypothesis argues that a highly concentrated banking sector poses a threat to the financial stability and generates systemic risk. Boyd and De Nicoló (2005) claim that an increased banking sector concentration, due to high market power of big banks and declining competition, may lead to lower interest rates on deposits and higher interest rates on loans. As banks will want to earn more in their loan markets by charging higher loan rates, at the same time the borrowers will face higher costs and an increase in their own risk of bankruptcy. This effect will be further strengthened by moral hazard on the borrowers' side, as they will adopt riskier projects to compensate for higher loan interest rates and loan repayment. Therefore, a decreased number of banks will lead to a higher level of loan portfolio risk, an increase of likelihood of defaults and therefore entail higher bank fragility.

Uhde and Heimeshoff (2008, pp. 21-23) used bank balance sheet data from commercial banks across the EU25 for the period from 1997 to 2005 and found that an increasing market concentration has a negative impact on financial soundness and that the negative impact of higher market concentration on financial stability occurs due to the fact that larger European commercial banks tend to engage in riskier investments than smaller banks. A similar result has also been obtained by Pawłowska (2015, p. 22), who did research to determine the relationship between competition, concentration and risk-taking and in the course of this examination she found, based on panel data analysis, that increasing the concentration and size of the banking sector within the EU-27 from period 2006-2010 had a negative impact on financial stability.

Many specialists also point out that as consolidation is a process of non-organic growth by acquiring assets of an acquired entity, the result is a creation of a new bank which is larger than the previously existing banks. What is more, the consolidation process may happen both within business lines but also across business lines, resulting in financial conglomerates that offer commercial and investment banking, insurance and pension fund services. Beck (2008) raises the argument that while consolidation has often been justified by efficiency, the process of consolidation and the resulting financial conglomerates have given rise to stability concerns - the size, complexity of these institutions might make it difficult for authorities to intervene and potentially close such institutions, a phenomenon knownas too big to fail (TBTF). In highly concentrated banking sectors regulators are more concerned about single big bank failures (due to, among other aspects, the market share, interconnectedness and effect of contagion) and therefore such banks are likely to receive public aid. These banks are too big to be allowed to collapse, and therefore the TBTF firms expect that failure will be prevented - thus they have an incentive to take greater risks than they otherwise would because they are shielded from at least some negative consequences of those risks (Labonte, 2015, p. 2). As a result, these banks may behave in a way, that makes it more likely they will go bankrupt (moral hazard).

There is also available research which tried to examine the relationship between concentration and soundness, but did not provide a definite answer. Kil (2015) examined this relationship in CEE countries using statistical analysis (examining correlation between $\mathrm{HHI}$, CR5, NPL and Z-score) and some countries with increasing asset concentration were more stable (Serbia, Croatia, Slovakia), while in others increasing concentration had

The article is an effect of the project - „Financialization- impact on the economy and society"- international conference, conducted by the University of Information Technology and Management in Rzeszów with Narodowy Bank Polski under the scope of economic education programme 
a negative impact (Slovenia, Estonia, Latvia, Romania). Research done byBen Ali, Intissar andZeitun (2015) provided support for the existence of both concentrationstability and concentration-fragility channels. The scientists confirmed both effects regarding concentration: the stabilizing and destabilizing effect on financial stability.

Scientists, regulators and banking professionals also indicate another concentration factor which is of great importance to the soundness of the financial sector the concentration of foreign ownership in the banking sector. There are many views which indicate advantages of foreign capital inflow into the banking sector, but also many which point at various dangers of foreign owners obtaining control over domestic banks. Galbis (1994, pp. 2-3) and Levine (1996, pp. 248-249) claim that entrance of foreign owned banks into the domestic market improves competition in the means of increasing quality and availability of banking products. Méon and Weill (2003) show that geographical diversification is also beneficial for banking institutions themselves and encourage cross-border activity. In their research they have shown that economic cycles of many European countries are not perfectly correlated, and therefore geographical diversification might play an important role in reducing banks' overall risk. In their opinion, a company that operates in several countries can limit its exposure to economic shocks and thereby reduce its risk.

However, according to Schoenmaker and Wagner's (2011, p. 23) research, due to the fact that many new EU Member States' banking sectors are dependent on capital from the "old" EU Member States, threat to stability of the euro zone has a strong impact on stability of other European countries. Hills and Hoggarth (2013, pp. 126128) also point out that cross-border bank flows can also give rise to financial stability risk through an increased vulnerability of domestic banks to external shocks. They also suggest that banks' increasing reliance on borrowing from abroad, especially from other banks and from their groups and parent entities, made them more vulnerable to funding risk and to shortage in foreign currency. Allen et al. (2011, p. 50) came to the conclusion that especially a shock to the capital base of parent banks may result in lower cross-border flows to their subsidiaries. As an example, they pointed at the 2007+ subprime crisis, which first undermined the equity position of the US banks, and then through the contagion effect, affected negatively equity positions of banks around the globe. What is also worth noting is that after the subprime crisis the importance of state capital in the banking sectors around the globe rose significantly, as governments had to bail out the bankrupting private banks with public money (Pawłowska, 2014b, p. 104).

Taking the abovementioned into consideration, especially the regulators face the challenge of deciding the consequences of ownership structure - is there an impact on the sector's soundness if banks are owned locally or are foreign owned?

\section{STRUCTURE AND CONCENTRATION OF The Banking SeCtor in POLAND}

One of the main structural changes which affects the concentration levels in a banking market are mergers \& acquisitions. The M\&A process has caused both a decrease in the number of banking institutions and, at the same time, an increase in market concentration and the size of the entities. The Polish banking sector is affected by this process as well, in the last years, mainly due to the 2007+ crisis. However, M\&A have been present in the Polish sector even beforehand, firstly after the privatization process and then after the accession of Poland to the EU.

In the mid-1990s, the main driver of consolidation in the banking sector in Poland was the takeover of banks in poor financial and economic conditions by investors with a strong capital base, as the overall level of own funds in the banking sector in Poland was low (Pawłowska, 2014b, p. 127). In 1997-2001 around 20 M\&As between private commercial banks took place in Poland. These transactions were a derivative of the privatization process, opening the market to foreign investors and global M\&As. The main foreign players which entered the Polish banking market via M\&As (through which they have established their subsidiaries) were, among others: KBC (Belgium), Citibank (USA), Deutsche Bank and HypoVereinsbank (both from Germany). The second significant wave of consolidation in the banking sector hit Poland as a result of the subprime crisis, as some strategic foreign investors of banks in Poland had to reduce their activity in foreign markets and decided to sell their Polish subsidiaries in order to restructure their activity (Polish Financial Supervision Authority [PFSA], 2013, p. 11).The ongoing consolidation of the banking sector in Poland,

The article is an effect of the project - „Financialization- impact on the economy and society”- international conference, conducted by the University of Information Technology and Management in Rzeszów with Narodowy Bank Polski under the scope of economic education programme 


\section{Chart 1: The number of commercial banks and branches of credit institutions operating in Poland in 2002-2014}

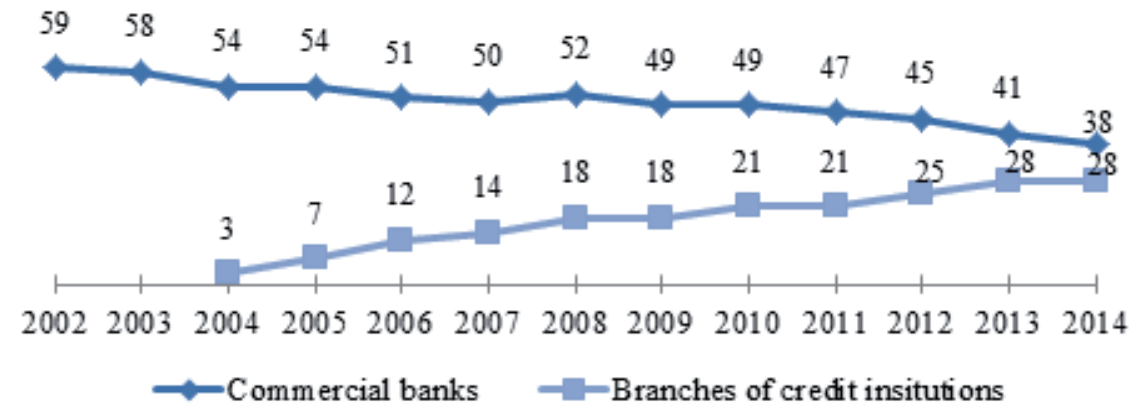

Source: Own elaboration based on PFSA, Raport o sytuacjibanków,editions: 2006-2014.

together with the principle of single authorization ${ }^{1}$, which introduced the possibility of converting a subsidiary of a foreign bank to its branch, caused a significant decrease in the number of commercial banks operating in Poland (see chart below).

Due to the abovementioned structural changes in the banking sector in Poland, the level of concentration (in terms of, inter alia, assets, loan portfolio, deposits from non-financial sector) was changing as well. When discussing the concentration ratios in the Polish banking sector, the two most common indicators of the sector concentration (Koutsomanoli-Fillipaki\&Staikouras, 2006, p. 448) will be used: the k-bank concentration ratios (CRk) and the Herfindahl-Hirschman Index ( $\mathrm{HHI})$. The CRkratio sums the shares of $k$ largest banks in the overall value of the market (or its particular segment). The $\mathrm{HHI}$ is the sum of squared shares of individual banks. This index has an

1 It is a principal which enables EU banks to operate in foreign markets as a branch of a credit institution - without establishing a separate subsidiary. upper value of 10,000 in the case of a monopolist bank and on the other hand it tends to 0 in the case of a large number of very small banks. The CR5 and CR10 indexes in terms ofassets and the $\mathrm{HHI}$ index for the banking sector in Poland in years 2007-2014 are presented in the chart below.

When analysing the concentration ratios of the banking sector in Poland one has to notice the slightdecrease of concentration in the years 2009-2011, which was mainly due to a slowdown in the consolidation. In turn in the years 2012-2014 the concentration started to rise again. However, even though the number of banks operating in Poland has significantly decreased and in the last years the level of concentration slightly fluctuated, in the long term the level of concentration of our domestic banking sector is stable with an upward trend (as may be seen in Chart 3).

\section{Chart 2: CR5 and CR10 indexes (in \%) in terms of assets and the HHI in Poland in 2007-2014}

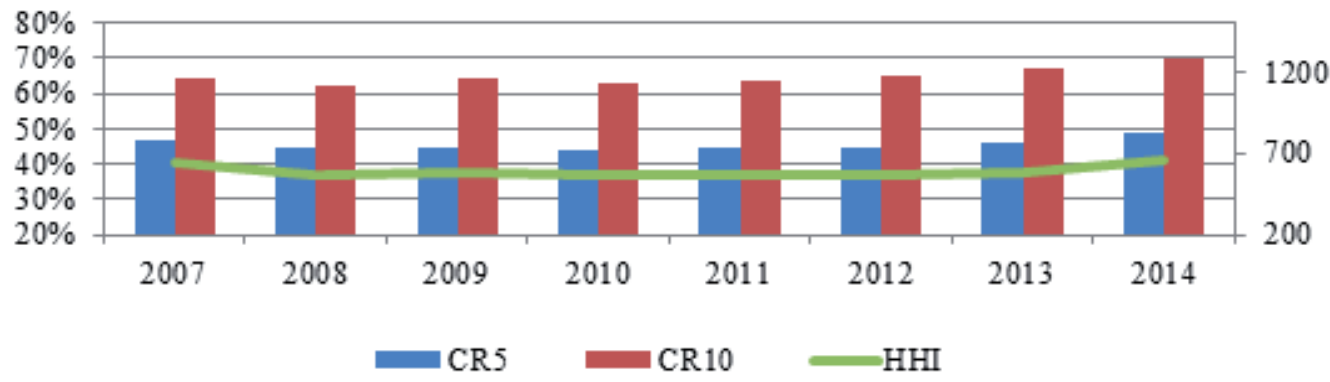

Source: Own elaboration based on PFSA, Raport o sytuacjibanków, editions: 2006-2014 and EBC, EU structural financial indicators: 2014

The article is an effect of the project - „Financialization- impact on the economy and society"- international conference, conducted by the University of Information Technology and Management in Rzeszów with Narodowy Bank Polski under the scope of economic education programme 
Chart 3: Changes is CR10 terms of assets, loans and deposits in years 2007-06.2015 in Poland
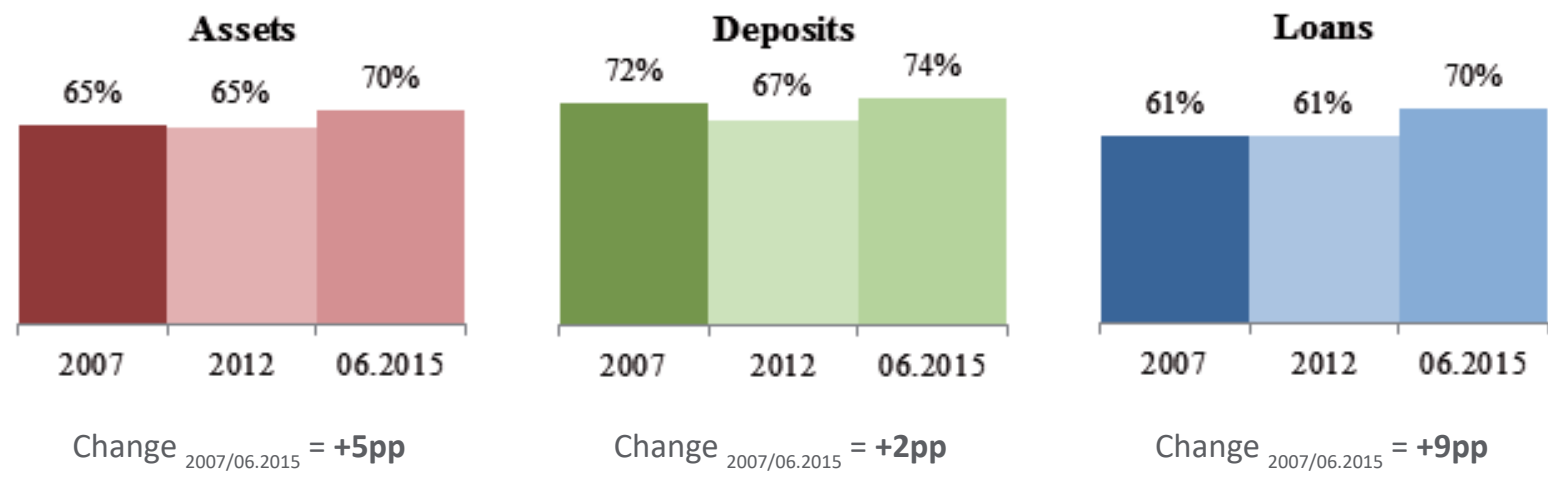

Source: own elaboration based on PFSA, Raport o sytuacjibanków,editions: 2007-1H2015

What is of great significance is that in the last years we have witnessed M\&As between key players in the Polish market (also between banks among the top 15). The key takeovers in the banking sector in Poland in the last years, together with changes in concentration levels, as well as the size of the newly formed institution, are portrayed in Table 1.

A significant rise in the concentration ratio took place in 2014 - it was mainly caused by the takeover of Nordea Bank Polska SA by PKO BP SA, the biggest bank in Poland. That explains the rise of the CR5 ratio by 2.4 pp and a $12 \%$ rise of the $\mathrm{HHI}$. Due to that merger, a bank with total assets amounting to 243761 was established, and therefore PKO BP SA strengthened its position as the biggest bank in Poland.

\section{Ownership structure in the Polish BANKING SECTOR}

The current ownership structure of the banking sector in Poland is the result of past experiences, mainly the privatization process.The economy in Poland in the 1980s was characterized by state ownership and central planning. The liberalization of the banking sector required

Table 1: Key mergers and acquisitions in the banking sector in Poland and their impact on concentration in 2012-2014

\begin{tabular}{|c|c|c|c|c|c|c|}
\hline & \multirow[b]{2}{*}{$\begin{array}{c}\text { Acquired bank (assets } \\
\text { before the merge in } \\
\text { m PLN) }\end{array}$} & \multirow[b]{2}{*}{$\begin{array}{l}\text { Merged bank (assets } \\
\text { as of 31.12.2014 in } \mathrm{m} \\
\text { PLN) }\end{array}$} & \\
\hline Year & $\begin{array}{l}\text { Acquirer (assets before } \\
\text { the merge in } \mathrm{m} \text { PLN) }\end{array}$ & & & $\mathrm{CR}_{5}$ & $\mathrm{CR}_{10}$ & HHI \\
\hline \multirow{2}{*}{2012} & $\begin{array}{l}\text { Getin Noble Bank SA } \\
(53 \text { 318) }\end{array}$ & GET Bank (957) & $\begin{array}{l}\text { Getin Noble Bank SA } \\
(67594)\end{array}$ & \multirow{2}{*}{$44.9 \%$} & \multirow{2}{*}{$64.7 \%$} & \multirow{2}{*}{568} \\
\hline & $\begin{array}{l}\text { Raiffeisen Bank Polska } \\
\text { SA ( } 27774)\end{array}$ & Polbank EFG SA (n/a) & $\begin{array}{l}\text { Raiffeisen Bank Polska } \\
\text { SA (53 521) }\end{array}$ & & & \\
\hline \multirow[b]{2}{*}{2013} & BZ WBK SA (59 196) & $\begin{array}{l}\text { Kredyt Bank SA } \\
\text { (40 259) }\end{array}$ & BZ WBK SA (121 607) & \multirow[b]{2}{*}{$46.1 \%$} & \multirow[b]{2}{*}{$67.3 \%$} & \multirow[b]{2}{*}{586} \\
\hline & $\begin{array}{l}\text { Polski Bank Przed- } \\
\text { siębiorczości SA } \\
(1 \text { 823) } \\
\end{array}$ & FM Bank SA (967) & $\begin{array}{l}\text { FM Bank PBP SA } \\
\text { (3 220) }\end{array}$ & & & \\
\hline \multirow{2}{*}{2014} & $\begin{array}{l}\text { Deutsche Bank PBC SA } \\
(27775)\end{array}$ & $\begin{array}{l}\text { Deutsche Bank Polska } \\
\text { SA (7 305) }\end{array}$ & $\begin{array}{l}\text { Deutsche Bank Polska } \\
\text { SA (35 288) }\end{array}$ & \multirow{2}{*}{$48.5 \%$} & \multirow{2}{*}{$70.0 \%$} & \multirow{2}{*}{656} \\
\hline & PKO BP SA (196 279) & $\begin{array}{l}\text { Nordea Bank Polska SA } \\
\text { (32 856) }\end{array}$ & PKO BP SA (243 761) & & & \\
\hline
\end{tabular}

Source: Own elaboration based on banks' financial statements

The article is an effect of the project - „Financialization- impact on the economy and society”- international conference, conducted by the University of Information Technology and Management in Rzeszów with Narodowy Bank Polski under the scope of economic education programme 
its de-monopolization and changes in its ownership structure. The Polish banking sector, due to liberalization of the licensing process, inflow of foreign capital and privatization, became a sector with domination of private ownership, mainly foreign. The regulators hoped that credible foreign investors would bring with them a strong capital base, know-how, improved management and advanced banking products. Since the mid-1990s, Poland has been playing the role of a host country for multiple banks from a number of countries in Europe and from the USA. In the following years changes in the ownership structure and the foreign capital domination were present due to the internal processes in the banking sector - an increase of share because of M\&A and ownership changes in foreign markets (Kornasiewicz\&Pugacewicz-Kowalska, 2002). The licensing process in Poland was oriented towards acquiring investors with a credible and strong capital base, therefore international banking groups with a strong capital base were welcomed. Of great importance was also the fact of Poland joining the EU in 2004, which intensified cross-border capital flows and FDI (Pawłowska, $2014 a$, p. 20). As a result of all of the abovementioned practices and systemic changes, the dominant position of foreign capital in banks in Poland was established.

As of the end of 2014, there were 38 commercial banks operating in Poland with 28 of them being banks controlled by foreign investors. There were also 28 branches of credit institutions, fully controlled by their foreign investors, however they only constituted 2,15\% of the banking sector's assets. The share of assets of the banking sector in Poland controlled by foreign investors as opposed to the Polish ownership in the last 8 years is portrayed in the chart below.

In the analysed period, only with the exception of 2008 when the share of assets controlled by foreign investors rose to $72.3 \%$ due to the entrance of two new banks with foreign capital: Alior Bank and Allianz Bank Polska, the share of assets owned by foreign investors was slowly diminishing. As of the end of 2014, 61.5\% of the banking sector in Poland's assets have been controlled by foreign capital. The increase of assets owned by domestic investors in 2014 was mainly due to the takeover of Nordea Bank by PKO BP.

The scale of engagement and significance of foreign capital in the banking sector in Poland is also portrayed by the share of ownership structure of 10 biggest banks (in terms of assets) operating in Poland. As of the end of 2014, out of the 10 biggest entities, 7 of them were controlled by foreign entities ( 6 of them from the EU and 1 from the USA). The share of these 7 foreign-owned banks in the 10 biggest is at the level of $64.54 \%$. The detailed ownership structure of the 10 biggest banks in Poland, together with source of capital and with indicated strategic investor is presented in the table below.

The vast majority of all banks operating in Poland are equipped with foreign capital coming from the "old" European Union Member States.The share of top foreign investors in assets in the Polish banking sector in 20072014 is presented in Table 3. During the analysed period two significant investors (from Ireland and Belgium)

Chart 4:The ownership structure of the banking sector in Poland in terms of share of assets

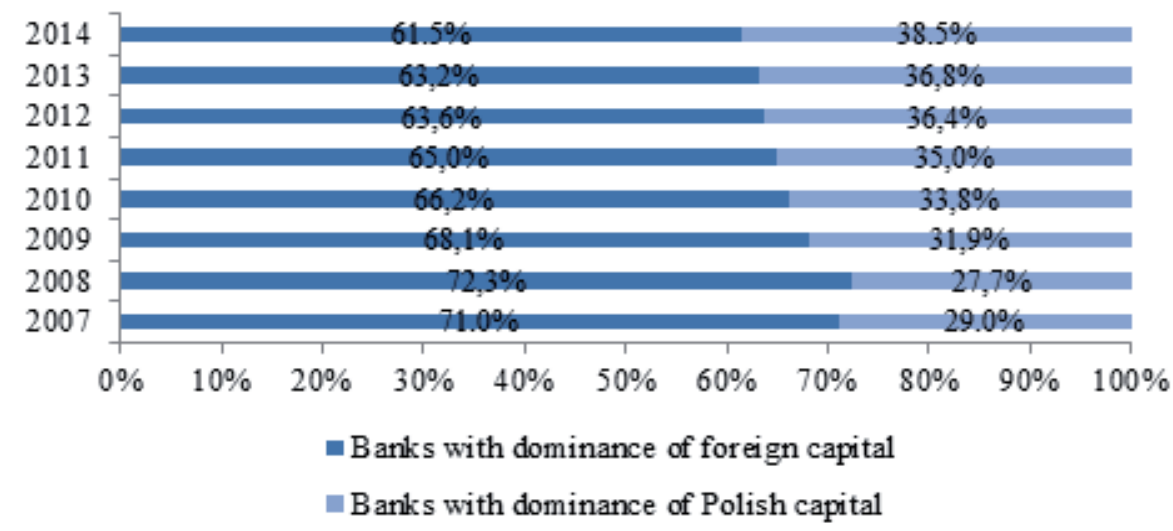

Source: Own elaboration based on PFSA, Raport o sytuacjibanków, editions 2007-2014

The article is an effect of the project - „Financialization- impact on the economy and society"- international conference, conducted by the University of Information Technology and Management in Rzeszów with Narodowy Bank Polski under the scope of economic education programme 
Table 2: Ownership structure of 10 biggest bank operating in Poland as of 31.12.2014

\begin{tabular}{|c|c|c|c|c|c|}
\hline$\#$ & Bank & $\begin{array}{l}\text { Assets } \\
\text { (m PLN) }\end{array}$ & Source of capital & $\begin{array}{l}\text { Ownership structure (structure of } \\
\text { share capital) }\end{array}$ & Strategic investor \\
\hline 1 & $\begin{array}{l}\text { Powszechna Kasa } \\
\text { Oszczędności } \\
\text { Bank Polski SA }\end{array}$ & 243761 & $\begin{array}{l}\text { bank with domina- } \\
\text { ting state capital }\end{array}$ & $\begin{array}{l}\text { - StateTreasury (31.39\%) } \\
\text { - Aviva Otwarty Fundusz Emerytalny } \\
\text { (6.72\%) } \\
\text { - ING Otwarty Fundusz Emerytalny } \\
\text { (5.17\%) } \\
\text { - other (56.72\%) }\end{array}$ & $\begin{array}{l}\text { State Treasury } \\
\text { (Poland) }\end{array}$ \\
\hline 2 & $\begin{array}{l}\text { Bank Polska Kasa } \\
\text { Opieki SA }\end{array}$ & 164323 & $\begin{array}{l}\text { private bank with } \\
\text { dominatingforeign } \\
\text { capital }\end{array}$ & $\begin{array}{l}\text { - UniCreditS.p.A. (50.10\%) } \\
\text { - other }(49.90 \%)\end{array}$ & $\begin{array}{l}\text { UniCreditS.p.A. } \\
\text { (Italy) }\end{array}$ \\
\hline 3 & $\begin{array}{l}\text { Bank Zachodni } \\
\text { WBK SA }\end{array}$ & 121607 & $\begin{array}{l}\text { private bank with } \\
\text { dominating foreign } \\
\text { capital }\end{array}$ & $\begin{array}{l}\text { - Banco Santander SA }(69.41 \%) \\
\text { - ING OFE }(5.15 \%) \\
\text { - other }(25.44 \%)\end{array}$ & $\begin{array}{l}\text { Banco Santander } \\
\text { SA (Spain) }\end{array}$ \\
\hline 4 & mBank SA & 113603 & $\begin{array}{l}\text { private bank with } \\
\text { dominating foreign } \\
\text { capital }\end{array}$ & $\begin{array}{l}\text { - Commerzbank AG }(69.5 \%) \\
\text { - other }(30.5 \%)\end{array}$ & $\begin{array}{l}\text { Commerzbank } \\
\text { AG (Germany) }\end{array}$ \\
\hline 5 & $\begin{array}{l}\text { ING Bank Śląski } \\
\text { SA }\end{array}$ & 96742 & $\begin{array}{l}\text { private bank with } \\
\text { dominating foreign } \\
\text { capital }\end{array}$ & $\begin{array}{l}\text { - ING Bank NV (75\%) } \\
\text { - Aviva OFE Aviva BZ WBK (5.66\%) } \\
\text { - other }(19.34 \%)\end{array}$ & $\begin{array}{l}\text { ING Bank NV } \\
\text { (Netherlands) }\end{array}$ \\
\hline 6 & $\begin{array}{l}\text { Getin Noble Bank } \\
\text { SA }\end{array}$ & 67594 & $\begin{array}{l}\text { private bank with } \\
\text { dominating Polish } \\
\text { capital }\end{array}$ & $\begin{array}{l}\text { - LC Corp BV (38.18\%) } \\
\text { - Leszek Czarnecki (9.99\%) } \\
\text { - ING OtwartyFunduszEmerytalny } \\
\text { (8.30\%) } \\
\text { - Getin Holding SA (7.56\%) } \\
\text { - Aviva OFE Aviva BZ WBK (6.58\%) } \\
\text { - other (29.39\%) }\end{array}$ & $\begin{array}{l}\text { Leszek Czarnecki. } \\
\text { PhD (Poland) }\end{array}$ \\
\hline 7 & $\begin{array}{l}\text { Bank Millennium } \\
\text { SA }\end{array}$ & 60484 & $\begin{array}{l}\text { private bank with } \\
\text { dominating foreign } \\
\text { capital }\end{array}$ & $\begin{array}{l}\text { - BancoComercialPortugues } \\
(65.51 \%) \\
\text { - ING OFE }(7.87 \%) \\
\text { - other }(26.62 \%)\end{array}$ & $\begin{array}{l}\text { BancoComer- } \\
\text { cialPortugues } \\
\text { (Portugal) }\end{array}$ \\
\hline 8 & $\begin{array}{l}\text { Raiffeisen Bank } \\
\text { Polska SA }\end{array}$ & 53521 & $\begin{array}{l}\text { private bank with } \\
\text { dominating foreign } \\
\text { capital }\end{array}$ & $\begin{array}{l}\text { - Raiffeisen Bank International AG } \\
(100 \%)\end{array}$ & $\begin{array}{l}\text { Raiffeisen Bank } \\
\text { International AG } \\
\text { (Austria) }\end{array}$ \\
\hline 9 & $\begin{array}{l}\text { Bank Gospodar- } \\
\text { stwaKrajowego }\end{array}$ & 51231 & state bank & - State Treasury (100\%) & $\begin{array}{l}\text { State Treasury } \\
\text { (Poland) }\end{array}$ \\
\hline 10 & $\begin{array}{l}\text { Bank Handlowy w } \\
\text { Warszawie SA }\end{array}$ & 49603 & $\begin{array}{l}\text { private bank with } \\
\text { dominating foreign } \\
\text { capital }\end{array}$ & $\begin{array}{l}\text { - Citibank Overseas Investment } \\
\text { Corporation }(75 \%) \\
\text { - other }(25 \%)\end{array}$ & $\begin{array}{l}\text { Citibank Overseas } \\
\text { Investment Cor- } \\
\text { poration (USA) }\end{array}$ \\
\hline
\end{tabular}

Source: Own elaboration based on banks' annual reports as of 31.12.2014

The article is an effect of the project - „Financialization- impact on the economy and society”- international conference, conducted by the University of Information Technology and Management in Rzeszów with Narodowy Bank Polski under the scope of economic education programme 
Table 3: Share of top foreign investors in the assets of the banking sector in Poland (in \%)

\begin{tabular}{|c|r|r|r|r|r|r|r|r|}
\hline Country & \multicolumn{1}{|c|}{$\mathbf{2 0 0 7}$} & \multicolumn{1}{|c|}{$\mathbf{2 0 0 8}$} & \multicolumn{1}{|c|}{$\mathbf{2 0 0 9}$} & $\mathbf{2 0 1 0}$ & $\mathbf{2 0 1 1}$ & $\mathbf{2 0 1 2}$ & $\mathbf{2 0 1 3}$ & $\mathbf{2 0 1 4}$ \\
\hline Italy & $17.1 \%$ & $12.9 \%$ & $13.0 \%$ & $12.4 \%$ & $12.5 \%$ & $12.7 \%$ & $13.1 \%$ & $12.9 \%$ \\
\hline Germany & $9.4 \%$ & $10.4 \%$ & $10.0 \%$ & $10.3 \%$ & $10.4 \%$ & $10.6 \%$ & $10.3 \%$ & $10.4 \%$ \\
\hline Spain & $1.0 \%$ & $1.0 \%$ & $1.0 \%$ & $1.5 \%$ & $5.7 \%$ & $5.4 \%$ & $8.5 \%$ & $9.1 \%$ \\
\hline Netherlands & $10.8 \%$ & $10.7 \%$ & $9.0 \%$ & $9.1 \%$ & $8.8 \%$ & $8.8 \%$ & $8.9 \%$ & $9.0 \%$ \\
\hline USA & $7.4 \%$ & $8.6 \%$ & $7.5 \%$ & $6.4 \%$ & $6.1 \%$ & $5.9 \%$ & $5.7 \%$ & $5.5 \%$ \\
\hline France & $5.7 \%$ & $6.5 \%$ & $6.7 \%$ & $5.8 \%$ & $5.1 \%$ & $4.8 \%$ & $4.7 \%$ & $4.9 \%$ \\
\hline Portugal & $3.7 \%$ & $4.5 \%$ & $4.2 \%$ & $4.0 \%$ & $3.9 \%$ & $3.9 \%$ & $4.1 \%$ & $4.0 \%$ \\
\hline Ireland & $5.0 \%$ & $5.4 \%$ & $5.0 \%$ & $4.5 \%$ & $0.0 \%$ & $0.0 \%$ & $0.0 \%$ & $0.0 \%$ \\
\hline Belgium & $3.6 \%$ & $3.9 \%$ & $3.8 \%$ & $3.8 \%$ & $3.3 \%$ & $3.1 \%$ & $0.0 \%$ & $0.0 \%$ \\
\hline
\end{tabular}

Source: Own elaboration based on PFSA, Raport o sytuacjibanków, editions: 2011-2014 and Kozak, S. (2013).

Consolidation of the Banking Sector in Poland in 1989-2013 in Comparison with the Structural Changes of the Banking Sector in the USA and EU, NBP Working Paper No. 166, Warsaw, p. 53-54

decided to leave the Polish banking sector. However, foreign ownership in Poland is well diversified: capital from only 2 foreign countries exceeds a $10 \%$ share of overall assets. As of the end of 2014, foreign investors from 17 different countries had controlling interest in banks operating in Poland, with a dominating share of investors from Italy, Germany, Spain and the Netherlands.

\section{CONCENTRATION ANDSOUNDNESS - Poland's EXPERIENCEAND EUROPEAN PRACTICE}

As it has already been described in the first section of this article, no consensus has been reached in the specialized scientific literature as to whether concentration endangers financial soundness orsupports it. However, the aim of this article is to assess the stability of the banking sector in Poland in current concentration and structural condition. There are 4 main methods of assessing and measuring stability of the financial sector: stability indicators, aggregated indexes, stress testing, network analysis and modelling. For the means of this article, the financial stability ratios method will be used. This assessment uses various groups of stability indicators (also known as financial soundness indicators - FSI) - Szczepańska groups them into three categories: indicators for banking systems, macroeconomic indicators and financial market indicators (Szczepańska, 2008, p. 171). FSI can be calculated in accordance with various methodologies, e.g. according to the IMF the most significant indicators regarding banking sectors include: quality of assets and capital, profitability and liquidity (Smaga, 2014, p. 32). In 2003 the IMF proposed a list of FSI (12 core and 27 encouraged) which should be monitored by specialized institutions responsible for supervision of individual financial entities as well as the systemic risk in the market. The chosen stability indicators of the commercial banking sector in Poland in 2009-2014 and of the five biggest banks operating in Poland as of 31.12.2014 assessed in line with chosen core stability ratios according to the IMF's methodology as well as national regulatory limits regarding liquidity (PFSA's Resolution No 386/2008on the establishment of liquidity standards binding for banks) are presented in Tables 4 and 5.

On the basis of the indicators listed above, there seem to be no threat of destabilization of the banking sector in Poland. The five biggest banks, which as of the end of 2014 constituted almost half of the market's assets $\left(C R_{5}=48,5 \%\right)$, were in line with prudential requirements regarding capital levels and liquidity and were profitable. Also, their loan portfolios were of good quality and did not stand out from the sector's average. It seems that the obtained level of asset concentration in the banking sector in Poland does not pose a threat to its stability under current economic conditions, as there is no evidence of stability disruption. The National Bank of Poland (2014) and the PFSA (2014) in their reports underline the soundnessof the Polish banking market. Also,the IMF (2013) assessed the Polish financial sector as resilient, profitable, well-capitalized and liquid.

However, even though all of the stability ratios in

The article is an effect of the project - „Financialization- impact on the economy and society"- international conference, conducted by the University

of Information Technology and Management in Rzeszów with Narodowy Bank Polski under the scope of economic education programme 
Table 4: Chosen FSI in the banking sector in Poland 2009-2014

\begin{tabular}{|c|c|c|c|c|c|c|c|}
\hline & & 2009 & 2010 & 2011 & 2012 & 2013 & 2014 \\
\hline \multirow{2}{*}{ Capital } & CAR & 13,3 & 13,8 & 13,1 & 14,7 & 15,7 & 15,3 \\
\hline & Tier1 ratio & & 12,4 & 11,7 & 13,1 & 14,2 & 14 \\
\hline \multirow{5}{*}{ Liquidity } & M1 (m PLN) & 112663 & 121680 & 123475 & 139019 & 132994 & 138882 \\
\hline & M2 & 1,49 & 1,54 & 1,44 & 1,53 & 1,46 & 1,43 \\
\hline & M3 & 4,34 & 4,97 & 5,22 & 5,85 & 5,93 & 6,13 \\
\hline & M4 & 1,23 & 1,22 & 1,16 & 1,19 & 1,2 & 1,21 \\
\hline & Loan/Deposit & & 107,2 & 109,4 & 106,5 & 103 & 100,1 \\
\hline Asset quality & NPL/loan portfolio & 7,1 & 7,8 & 7,3 & 7,7 & 7,4 & 7 \\
\hline \multirow{3}{*}{ Profitability } & ROE & 8,62 & 10,21 & 12,64 & 11,16 & 9,99 & 10,3 \\
\hline & ROA & 0,81 & 1,03 & 1,26 & 1,22 & 1,09 & 1,11 \\
\hline & Financial result (m PLN) & 8282 & 11420 & 15539 & 15467 & 15175 & 16224 \\
\hline
\end{tabular}

Source: Own elaboration based on PFSA, Raport o sytuacjibanków, editions: 2009-2014 and PFSA's data as of 30.09.2015: https://www.knf.gov.pl/Images/2015_09-SEKTOR_BANKOWY-DANE_tcm75-33691.xIsx (12.11.2015)

Table 5: Chosen FSI in the five biggest banks in Poland as of 31.12.2014

\begin{tabular}{|c|c|r|r|r|r|r|}
\hline \multirow{2}{*}{ Capital } & PKO BP SA & Pekao SA & BZ WBK SA & mBank SA & $\begin{array}{c}\text { ING Bank } \\
\text { Sląski SA }\end{array}$ \\
\hline \multirow{2}{*}{ Liquidity } & CAR & 13 & 17,1 & 12,9 & 14,7 & 15,5 \\
\hline \multirow{2}{*}{ Asset quality } & Tier1 ratio & 11,7 & 17,1 & $\mathrm{n} / \mathrm{a}$ & 12,2 & 14,2 \\
\hline \multirow{2}{*}{ Profitability } & NPL/loan portfolio & 1,08 & 1 & 0,96 & 1,07 & 0,83 \\
\cline { 2 - 7 } & ROE & 8,1 & 6,8 & 7,7 & 8,1 & 3,4 \\
\cline { 2 - 7 } & ROA & 12,3 & 11,4 & 12,6 & 12,1 & 10,9 \\
\hline & Financial result & 1,5 & 1,7 & 1,6 & 1,2 & 1,1 \\
\hline
\end{tabular}

Source: Own elaboration based on banks' annual reports as of 31.12.2014

the banking sector in Poland are satisfactory and the sector's condition is described as stable, on 13 June 2013 the national supervisor - Polish Financial Supervision Authority, issued a special announcement regarding the asset concentration in the Polish financial market (PFSA, 2013). According to the PFSA, at that time the level of concentration in the Polish banking sector was close to optimum. The supervisor emphasized that from the point of view of the systemic risk and the safety of the sector, it is of great importance that there are no banking institutions in Poland which could be considered too big (and therefore their eventual problems could not be solved with national crisis management instruments). In this statement the PFSA indicated that any attempt at further consolidation especially among the big banks (significant to the Polish sector) would be met with a reserved reaction and will be precisely analysed (both in terms of impact on the involved entities as well as on the The article is an effect of the project - „Financialization- impact on the economy and society"- international conference, conducted by the University of Information Technology and Management in Rzeszów with Narodowy Bank Polski under the scope of economic education programme

www.e-finanse.com level of systemic risk). However, one has to note that the "optimal level" has never been quantified or specified in any way.

The abovementioned statement has been a signal sent to the market that further consolidation is not a desired means of growth and a way of pointing out that high concentration in the banking sector may be a cause of systemic risks. According to the regulator, the banking sector in Poland is almost concentrated enough and there is not much space for further consolidation. However, when drawing conclusions regarding the banking sector situation it is of great advantage to compare it with situations in other countries. In the case of Poland the most natural peer group are the EU Member States.

Taking into consideration the result presented in the chart above, it would seem that there is still a lot of space available for further consolidation in Poland. As of 
Chart 5: CR5 in terms of assets across the EU Member States as of 31.12.2014

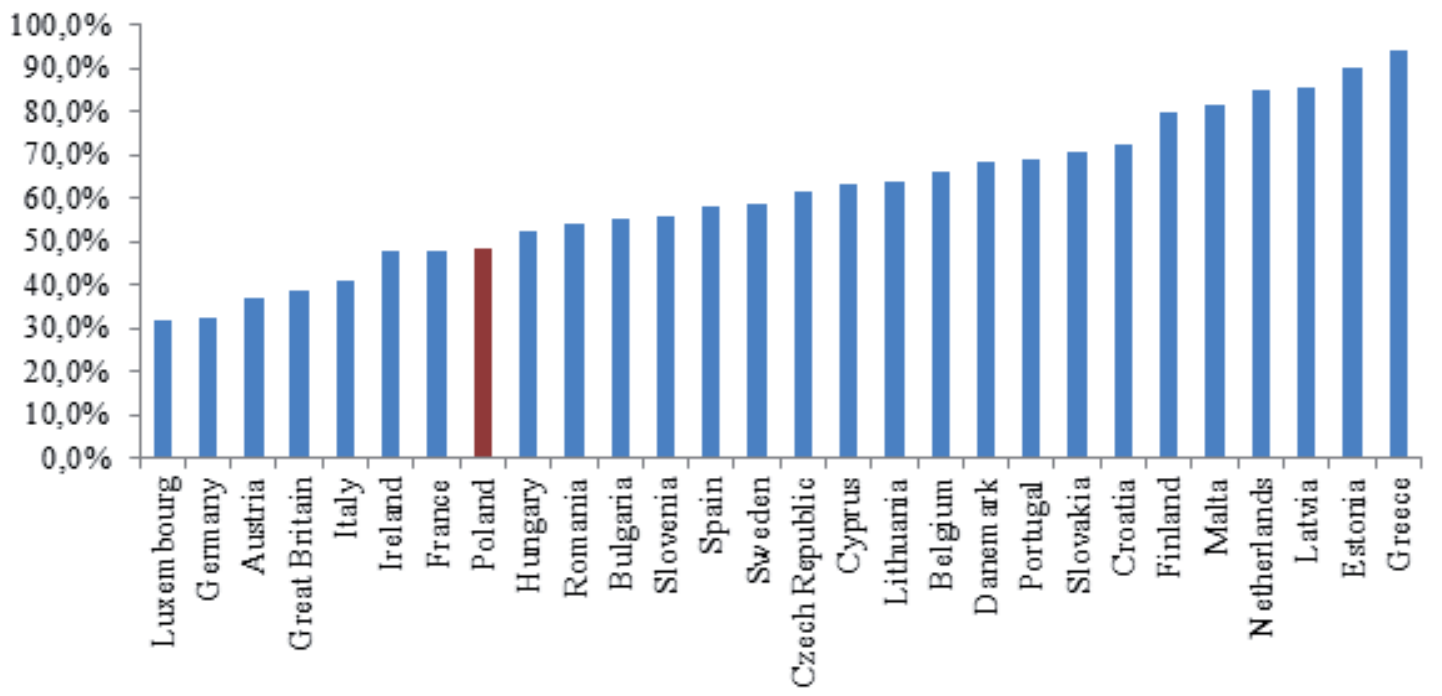

Source: Own compilation based on data from: EBC, EU structural financial indicators: 2014

the end of 2014, the $\mathrm{CR}_{5}$ in Poland was at $48.5 \%$ and with the EU-28 average of $61.03 \%$, Poland was in the group of countries with the lowest concentration ratio, near France, Ireland, Italy, Great Britain, Austria, Germany and Luxembourg. On the other hand, some countries with well-developed banking markets are characterized by higher concentration (e.g. Portugal or Sweden). A very high level of concentration can be observed also in the Netherlands with $\mathrm{CR}_{5}$ at $85 \%$. The Dutch banking sector is one of the biggest and most-developed in Europe. However, the Dutch central bank - De Nederlandsche Bank (2015) - in its report Perspective on the structure of the Dutch banking sector also pointed out that the Dutch banking sector should become more diverse and more competitive, which will increase the soundness and efficiency of banking services. The central bank pointed out that the failure of a bank with a large market share could pose a threat to the stability of banking services in these conditions. DNB admitted that it welcomes the entry of new market participants.

The banking sector with the highest $\mathrm{CR}_{5}$ ratio among all of the EU Member States is Greece, with the ratio levelling at $94,1 \%$. The increasing banking sector concentration in Greece is a result of deep banking sector restructuring processes, as larger banks acted as consolidators in resolutions of non-viable entities, and of withdrawal of foreign players. The turmoil happening in the banking sector in Greece resulted in decrease in operating profit and capital decline (European Central Bank, 2014, p. 23, 28). Also, the NPL/loans ratio is at an exceptionally high level of $55 \%$ with an average $41 \%$ at Greece's four biggest banks (Bird, 2015). Due to a very high concentration ratio, a possible bankruptcy of one of the Greek banks would be destructive to the whole sector.

Due to the poor situation in the Greek economy and its banking sector, on 8 July 2015 Greece requested stability support in the form of an ESM loan, which was assessed by the European Commission in liaison with the ECB. One of the arguments in favour of granting the loan was that "Greek banks still have a number of branches and subsidiaries in other countries which could cause spillover effects. (...) In some of the EU member states Greek banks' subsidiaries account for $15-25 \%$ of the local banking sector which make them systemically important. Adverse development in the Greek banking sector has the potential to create financial instability in these countries" (European Commission, 2015, p. 5). This argument especially shows that there is one more important factor which needs to be taken into consideration while deciding about further market entry by other banks and further consolidation - it is the factor of geographic concentration - namely the share of capital coming from foreign countries in the domestic banking sector, especially due to the ever-present contagion effect as well as due to numerous linkages of foreign subsidiaries with their parent groups.

As portrayed in the third section of this article, the Polish banking sector is dominated by banks with foreign strategic investors. These banks are subsidiaries of European or worldwide banking groups. Any eventual

The article is an effect of the project - „Financialization- impact on the economy and society"- international conference, conducted by the University of Information Technology and Management in Rzeszów with Narodowy Bank Polski under the scope of economic education programme 
problems of these banking groups would lead to disruptions not only in the group's home country, but in the host countries (including Poland) as well (IwaniczDrozdowska, 2008, p. 42). So far, the present ownership structure has not played any threatening role to the soundness of the banking market in Poland, however, there have been some factors which highlight the importance of diversifying the ownership structure.

Due to connections between international banking groups, there are many funding flows between entities. Polish banks, which are members of international groups and have foreign parent banks, are to a high degree financed through funding from the group: deposits from the financial sector, loans, subordinated debts, etc. There is a high possibility that in the case of any potential problem, the level of funding received from the group may decrease and in turn affect liquidity in Polish subsidiaries. Currently many parent banks of Polish subsidiaries still face problems resulting from the financial crisis. For example, recently Commerzbank AG (owner of mBank SA) and Deutsche Bank AG (owner of Deutsche Bank Polska $\mathrm{SA}$ ) have paid enormous settlements (in height of 1.45 bn USD and 2.5 bn USD respectively), which may have an impact on the financial situation of their respective groups. Any potential results regarding Polish subsidiaries will have to be determined in the future. Pawłowska, Serwa and Zajączkowski (2014, p. 4) analysed how funding liquidity shocks, which affected large international banks, were transmitted to Polish subsidiaries and branches in recent years. They examined the liquidity shocks caused by the 2007+ financial crisis. At the end of 2008 there was a sudden depreciation of the PLN (by more than $30 \%$ against euro), which quickly increased the value of assets (e.g. foreign currency loans). Only a portion of a large portfolio of foreign currency loans (mostly long-term mortgage loans) was financed with liabilities in foreign currencies and the resulting open foreign exchange position on the balance sheets of Polish banks was hedged with foreign exchange derivatives (FX swaps and CIRS). The depreciation of local currency increased funding needs of the Polish banks. At the same time the interbank market froze and deposit transactions were almost nonexistent. This first wave of shocks caused temporary funding problems for Polish banks, however most of the foreign parents were able to provide additional funding (especially in foreign currencies) to their subsidiaries or branches. The result of the constructed econometric model suggests that "the intragroup links between

The article is an effect of the project - „Financialization- impact on the economy and society”- international conference, conducted by the University

of Information Technology and Management in Rzeszów with Narodowy Bank Polski under the scope of economic education programme 
Due to all of the abovementioned arguments, the ownership structure of the banking sectors, as well as the geographic concentration of foreign capital, are of greatest importance. Hypothetically speaking, if there is a significant number of banks with foreign investors coming from one country - there is a high risk that if there is a crisis in that country that due to the spillover effect the consequences will be present in the host country as well. Looking at various experiences of other EU countries, regulators aim at diversification of geographic structure or at mitigating the geographic concentration risk. In the case of the Netherlands, foreign banks do not play a prominent role. In 2009 the Netherlands ranked as first in Europe in terms of dominance of domestic banking players. As of the end of 2014, approximately $10 \%$ of Dutch banking assets were owned by foreign investors, of which $85 \%$ originated from the EU. However, in July 2015 the Dutch central bank encouraged foreign investors to enter the Dutch banking market with the aim to increase diversity and competition in order to maintain stability of the sector.

On the other hand, the Western Balkan region is characterized by very high asset concentration and share of foreign capital. One of the countries belonging to this region is Albania, with $90 \%$ of total banking assets held by foreign investors with the largest five banks holding about three-quarters of system assets and deposits. Over $6,5 \%$ of the sector's assets were held by Greek parent banks, which due to their internal problems have also cut lending in their host countries (in the case of Albania by $20 \%$ ), which poses a threat to Albania's sector stability. The IMF, while assessing stability of the Albanian banking sector stated that difficulties in parent countries can affect Albanianinstitutions through direct contagion, defunding pressures, or higher NPLs (IMF, 2014, p. 14).

Another example of high asset and geographic concentration are Baltic and Nordic countries, whose banking sectors are very interwoven, with a few large banks dominating this region. The three largest Scandinavian banks: SEB, Swedbank and DnB NORD, controlled thelargest share of the Baltic States' banking system assets - at the end of 2009, Scandinavian bank groups together had around $75 \%$ of the total Baltic countries banking system's assets under their control. As of 1Q2011 98\% of assets in the Estonian banking sector was held by foreign players and the biggest bank in Estonia, Swedbank Tallinn, had a share of $78.5 \%$ in the domestic banking sector assets (Markiewicz, 2011, p. 11). Also, the three biggest Lithuanian banks are Scandinavian.The Baltic countries were strongly hit by 2007+ financial crisis, with considerable credit losses, with the biggest losses reported by Scandinavian parent banks. In 2009 Swedbank and SEB groups accounted their euro loan portfolio impairment losses for respectively EUR 2.4 bn and EUR 1.2 bn, of which $61 \%$ and $78 \%$ derived from the Baltic countries (Markiewicz, 2011, p. 15). The Baltic and Nordic countries have acknowledged this strong independence and took action to mitigate this generated risk. On 17 August 2010 these countries signed the document Cooperation agreement on cross-border financial stability, crisis management and resolution between relevant Ministries, Central Banks and Financial Supervisory Authorities of Denmark, Estonia, Finland, Iceland, Latvia, Lithuania, Norway and Sweden. This Memorandum of Understanding strengthens the preparedness for dealing with cross-border financial stability issues in the Nordic-Baltic region, as it has been established to facilitate the management and resolution of cross border systemic crises in this region. One of the provisions of the abovementioned agreement states that "The Parties have signed this agreement in recognition of the fact that a financial crisis involving a Relevant Financial Group could pose a threat to the stability of the financial system in several of their countries. The Parties therefore commit themselves to best efforts to follow the spirit of this agreement when cooperating in the management and resolution of a crisis situation". Any problems of a domestic nature are excluded from this cooperation agreement. The idea of this burden-sharing scheme is to share both benefits and costs of an integrated banking system among the countries in the Nordic and Baltic region. The Baltic and Nordic countries have thus recognized the geographic concentration risk in their banking sectors and have taken steps to mitigate the generated cross-border banking risk in their region.

\section{Conclusions}

The issue of banking sector asset and ownership concentration is of interest to regulators and others concerned about potential market disruption. This issue is also widely discussed in appropriate economic literature. Yet still no consensus has been reached regarding the link between banking concentration and financial soundness,

The article is an effect of the project - „Financialization- impact on the economy and society"- international conference, conducted by the University of Information Technology and Management in Rzeszów with Narodowy Bank Polski under the scope of economic education programme 
as both empirical evidence and economic theory provide conflicting predictions as to whether concentrated banking sectors are more or less stable. However, it is without a doubt that due to the intensification of crossborder banking, the intragroup links serve as a channel for shock transmission and may lead to a spillover effect. As it has been proved in the article, the regulators encourage market diversification in the banking sector concentration, either by inviting foreign capital into highly concentrated markets with dominance of domestic banking players (the case of the Netherlands) or by trying to mitigate risk generated by the dominance of geographically concentrated cross-border banking (as in the case of the cooperation agreement established in Baltic and Nordic States). The analysis of empirical evidence carried out in this study confirmed the thesis that limited concentration with diversification of the ownership structure favours stability of a banking system.

An analysis of how the Polish banking market has changed throughout the years has proved that there has been a slight increase in asset concentration. Yet our domestic sector, with $\mathrm{CR}_{5}$ at $48.5 \%$, is way below the EU-28 average, therefore according to various experts, leaving a lot of space for further consolidation. As for the structure of ownership, the Polish banking sector is strongly dominated by banks owned by foreign players ( $68.5 \%$ as of the end of 2014), with geographically diversified sources of capital - coming from 17 countries (however most of them from the EU). Nonetheless, the PFSA in 2013 issued a statement to the effect that the concentration of the banking sector in Poland is optimal and from the point of view of systemic risk, it is of great importance that there are no banking institutions in Poland which could be considered too large. Some experts even point out that the geographical diversification of parent banks of Polish subsidiaries and their different characteristics helped the domestic financial system to remain stablethrough the 2007+ financial crisis (Pawłowska et al., 2014, p. 21).

\section{REFERENCES}

Allen, F., Beck, T., Carletti, E., Lane, P.R., Schoenmaker, D., Wagner, W. (2011). Cross-Border Banking in Europe: Implications for Financial Stability and Macroeconomic Policies. London: Centre for Economic Policy Research.

Beck, T. (2008). Bank Competition and Financial Stability: Friends or Foes?. World Bank Policy Research Working Paper No. 4656.

Beck, T., Demirgüç-Kunt, A., Levine, R. (2003). Bank Concentration and Crises. NBER working paper series, Working Paper no. 9921, 1-43. Retrieved from http://www.nber.org/papers/w9921.pdf.

Ben Ali, M.S., Intissar, T., Zeitun, R. Banking Concentration and Financial Stability: Evidence from Developed and Developing Countries. Economics Discussion Papers, No 2015-22, Kiel Institute for the World Economy. Retrieved from http://www.economics-ejournal.org/economics/discussionpapers/2015-22.

Berger, A.N., Klapper, L.F., Turk-Ariss, R., Bank Competition and Financial Stability, World Bank. Policy Research Working Paper 4696. Retrieved from: http://documents.worldbank.org/curated/en/121111468339560931/pdf/WPS4696. pdf.

Bird, M. (2015). Even a Bailout Deal Can't Revive Greece's Shattered Banking System. Retrieved from http:// uk.businessinsider.com/a-greek-bailout-deal-cant-help-greek-banks-2015-7.

Boyd, J.H., De, Nicoló G. (2005). The Theory of Bank Risk-Taking and Competition Revisited. Journal of Finance 60(3), 1329-1343.

Cooperation agreement on cross-border financial stability, crisis management and resolution between relevant Ministries, Central Banks and Financial Supervisory Authorities of Denmark, Estonia, Finland, Iceland, Latvia, Lithuania, Norway and Sweden. (17.08.2010). Retrieved from http://www.riksbank.se/Upload/Dokument_riksbank/Kat AFS/2010/8a37263c.pdf.

Craig, B.R., Dinger, V. (2010). Deposit Market Competition, Wholesale Funding, and Bank Risk. European Banking Center Discussion Paper, No. 210-17S, 1-34.

Davis, K. (2007, August). Banking Concentration, Financial Stability and Public Policy. Paper presented at the Conference on The Structure and Resilience of the Financial System, Sydney, Australia.

De Nederlandsche Bank (2015). Perspective on the Structure of the Dutch Banking Sector, 1-64. Retrieved from http:// www.dnb.nl/en/binaries/DNB-study\%20Perspective\%20on\%20the\%20 structure\%20of\%20the\%20Dutch\%20 banking\%20sector_tcm47-323322.pdf.

European Central Bank (2014). Banking Structures Report, 1-63.

European Commission (2015). Greece - request for stability support in the form of an ESM loanAssessment of: a) the existence of a risk to the financial stability of the euro area; b) whether public debt is sustainable. c) the actual or

The article is an effect of the project - „Financialization- impact on the economy and society"- international conference, conducted by the University of Information Technology and Management in Rzeszów with Narodowy Bank Polski under the scope of economic education programme 
potential financing needs. (in compliance with Art 13 of ESM Treaty).

Galbis, V. (1994). Sequencing of Financial Sector Reforms: A Review. IMF Working Paper WP/94/101, 1-32.

Gozdek, M., Kawalec, S. (2012, August). Raport dotyczqcy optymalnej struktury polskiego systemu bankowego w średnim okresie. Paper presented at National Bank of Poland's Seminar on Bank Ownership Structure in Poland, Warsaw, Poland.

Heimeshoff, U., Uhde, A. (2008). Consolidation in Banking and Financial Stability in Europe. The Case of Promoting Crossborder Bank Mergers. Retrieved from http://www.uni-graz.at/socialpolitik/papers/Uhde.pdf.

Hills, B., Hoggarth, G. (2013). Cross-border Bank Credit and Global Financial Stability. Bank of England Quarterly Bulletin, 126-136.

International Monetary Fund (2014). Albania. Financial System Stability Assessment. IMF Country Report No. 14/79, $1-95$.

International Monetary Fund (2013). Republic of Poland: Financial System Stability Assessment. IMF Country Report No. $13 / 221,1-41$

Iwanicz-Drozdowska, M. (2008). Bezpieczeństwo rynku usług finansowych. Warsaw: Oficyna Wydawnicza SGH.

Kil, K. Poziom koncentracji a stabilność finansowa sektorów bankowych krajów Europy Środkowo-Wschodniej. Zeszyty Naukowe Szkoły Głównej Gospodarstwa Wiejskiego Ekonomika i Organizacja Gospodarki Żywnościowej, nr 110, 2015.

Kindleberger, C.P. (1978). Manias, Panics and Crashes: A History of Financial Crisis. New York: Basic Books.

Kornasiewicz, A., Pugacewicz-Kowalska, I. (2002). Znaczenie prywatyzacji dla rozwoju polskiego sektora bankowego. Retrieved from http://www.case-research.eu/upload/publikacja_plik/bre61_3.pdf.

Koutsomanoli-Fillipaki, N., Staikouras, Ch. (2006). Competition and Concentration in the New European Banking Landscape. European Financial Management, Vol. 12, No. 3, 443-482.

Kozak, S. (2013). Consolidation of the Banking Sector in Poland in 1989-2013 in Comparison with the Structural Changes of the Banking Sector in the USA and EU. NBP Working Paper, No. 166, 1-56.

Labonte, M. (2015). Systemically Important or "Too Big to Fail" Financial Institutions. Congressional Research Service Report, 1-60. Retrieved from https://www.fas.org/sgp/crs/misc/R42150.pdf.

Levine, R. (1996). Foreign Banks, Financial Development and Economic Growth. In C.E. Barfield (Ed.), International Financial Markets (pp. 224-254). Washington: AEI Press.

Markiewicz, M. (2011, February). The Concentration and Competition in the Banking Sectors of the Baltic States in the Context of a Crisis. Paper presented at the Bremen University of Applied Sciences' Workshop: The Baltic States at Crossroads? Options and Strategies for Sustainable Economic Growth in the Aftermath of the Global Financial Crisis. Bremen, Germany.

Méon, P-G.,Weill, L. (2003). Mergers in Europe Help Banks Hedge against Macroeconomic Risk?. LARGE Universite Robert Schuman, Papier No 59.

Minsky, H. (1982). The Financial Instability Hypothesis: Capitalistic Processes and the Behavior of the Economy. In C.P. Kindleberger, J-P. Laffargue (Ed.), Financial Crises: Theory, History, and Policy, Cambridge: Cambridge University Press.

Narodowy Bank Polski (2014). Rozwój systemu finansowego w Polsce w 2013 r., 1-354.

Pawłowska, M. (2015). Changes in the Size and Structure of the European Union Banking Sector - the Role of Competition between Banks. NBP Working Paper, No. 205. 1-38.

Pawłowska, M. (2014a). Jak kształtowała się konkurencja w sektorze bankowym w Polsce i w Europie przed kryzysem i w okresie kryzysu. In E. Balcerowicz (Ed.), Zeszyty mBank - CASE, nr 134/2014, Warsaw: CASE - Centrum Analiz Społeczno-Ekonomicznych - Fundacja Naukowa.

Pawłowska, M. (2014b). Konkurencja w sektorze bankowym. Warsaw: C. H. Beck.

Pawłowska, M., Serwa, D., Zajączkowski, S. (2014). International Transmission of Liquidity Shocks between Parent Banks and their Affiliates: the Host Country Perspective. NBP Working paper, No. 172, 1-38.

Polish Financial Supervision Authority (2013). Komunikat $w$ sprawie koncentracji w rynku bankowym. Retrieved from https://www.knf.gov.pl/Images/KNF_koncentracja_na_rynku_bankowym_13_06_2013_tcm75-34800.pdf.

Polish Financial Supervision Authority (2007-2015). Raport o sytuacji banków. Editions: 2007-2014.

Schoenmaker, D., Wagner, W. (2011). The Impact of Cross-Border Banking on Financial Stability. Duisenberg School of Finance - Tinbergen Institute Discussion Paper. TI 11-054 / DSF 18, 1-30.

Smaga, P. (2014). Pomiar stabilności finansowej i rola banku centralnego. Bezpieczny Bank, No 4(57), 28-53.

Szczepańska, O. (2008). Stabilność finansowa jako cel banku centralnego. Warsaw: SCHOLAR.

Tabak, B.M., Guerra, S.M., Lima, E.J.A., Chang, E.J. (2007). The Stability-Concentration Relationship in the Brazilian Banking System. Banco Central Do Brasil Working Paper, Np. 145, 1-30.

The article is an effect of the project - „Financialization- impact on the economy and society"- international conference, conducted by the University of Information Technology and Management in Rzeszów with Narodowy Bank Polski under the scope of economic education programme 